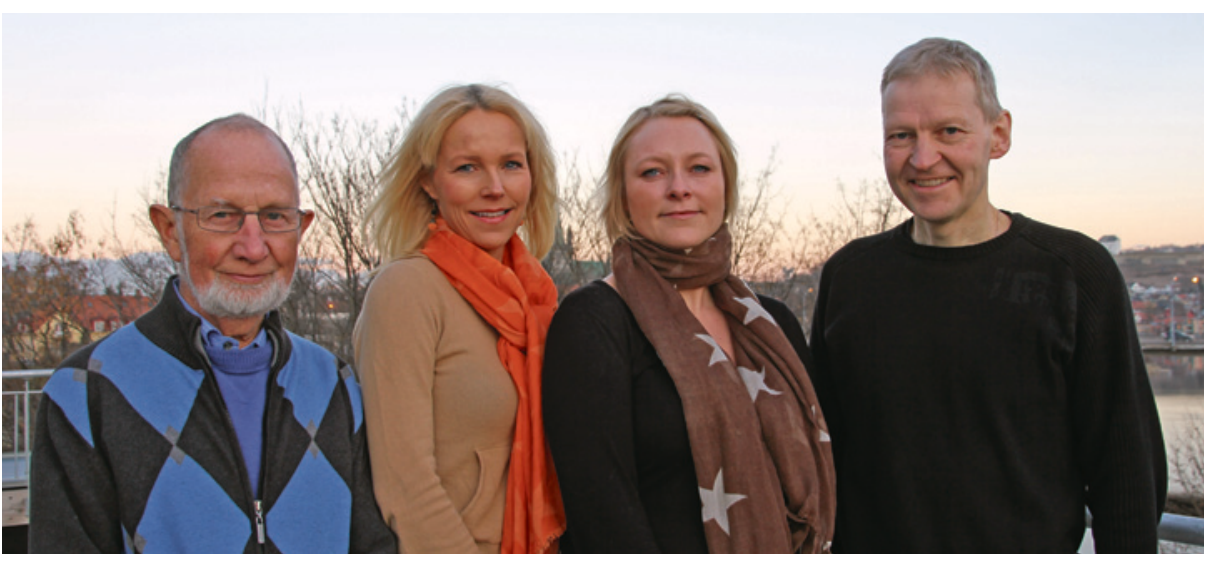

Fire av de seks forfatterne. Fra venstre: Jørn Bathen, Berit Nordstrand, Marianne Stallvik og Olav Spigset. Øistein Kristensen og Eirik Skogvoll var ikke til stede da bildet ble tatt. Foto Katrin Øien
Ordforklaringer

QT-tid: Tiden fra starten av Q-takken til slutten av T-takken i EKG. Forlenget QT-tid er assosiert med økt risiko for alvorlige hjertearytmier av typen torsades de pointes.

Enantiomerer: Speilvendte former av et molekyl, analogt med vår høyrehånd og venstrehånd Mange legemidler, inklusive metadon, forekommer i to slike speilvendte former.

Racemat: En 50/50-blanding av to enantiomerer av et legemiddel. Metadon gis som et racemat.

\title{
QT-tid ved bruk av metadon og buprenorfin
}

\begin{abstract}
Rutinemessig EKG-måling er ikke nødvendig før og etter oppstart hos pasienter som skal behandles med metadondoser på under $100 \mathrm{mg} / \mathrm{d} ø \mathrm{gn}$, ifølge ny norsk forskning. Buprenorfin kan være et godt alternativ til metadon.
\end{abstract}

Det er kjent at metadon i høye doser, dvs. over ca. $100 \mathrm{mg} / \mathrm{d}$, kan øke QT-tiden og dermed øke risikoen for ventrikkelarytmier av typen torsades de pointes. Det er mer usikkert om doser på under $100 \mathrm{mg} / \mathrm{d}$ er assosiert med en signifikant økt forlengelse av QT-tiden. Norske forskere har tidligere undersøkt om det er den aktive (R)-enantiomeren eller den inaktive (S)-enantiomeren av metadon som er assosiert med denne økningen. Resultatene tydet på at den aktive (R)-enantiomeren er viktigst, mens andre studier har pekt på at den inaktive (S)-enantiomeren har størst betydning. Det er i langt mindre grad undersøkt hvorvidt behandling med buprenorfin kan påvirke QT-tiden.

For å belyse dette nærmere utførte forskerne en prospektiv tosenterstudie over seks måneder der 80 pasienter fikk behandling med enten metadon $(n=45)$ eller buprenorfin $(n=35)(1)$. Gjennomsnittlig dosering var $88 \mathrm{mg} / \mathrm{d}$ for metadon og $16 \mathrm{mg} / \mathrm{d}$ for buprenorfin. Det var ingen sammenheng mellom bruk av metadon eller bruk av buprenorfin og individuelle endringer i frekvenskorrigert QT-intervall (QTc). Det var heller ingen sammenheng mellom metadondosen eller serumkonsentrasjonen av (S)-metadon, (R)-metadon eller total-metadon og endring i QTc. Heller ikke for buprenorfin var det noen sammenheng mellom dose eller serumkonsentrasjon og endring i QTc. Derimot fant man en sammenheng mellom lave kaliumnivåer og økning av QT-tiden, og at kvinner hadde noe lengre QT-tider enn menn.

- Resultatene tyder på at rutinemessig EKG-måling før og etter oppstart ikke er nødvendig hos pasienter som skal behandles med metadondoser på under $100 \mathrm{mg} / \mathrm{d}$, såfremt pasienten ikke har kjent hjertesykdom fra før eller behandles med andre legemidler som kan interagere med metadon eller som i seg selv kan øke QTtiden, sier sisteforfatter Olav Spigset ved St. Olavs hospital. Våre resultater viser også at buprenorfin ser ut til å være et sikkert alternativ til metadon. Buprenorfin bør derfor velges fremfor metadon hos pasienter som har hatt økning i QT-tiden med metadon eller som har kjent forlenget QT-tid fra tidligere, sier Spigset.

\section{Forskningsgruppen}

Studien er et samarbeid mellom Rusbehandling Midt-Norge, Avdeling for rusog avhengighetsbehandling ved Sørlandet sykehus Kristiansand, og Avdeling for klinisk farmakologi ved St. Olavs hospital. Artikkelen er skrevet av Marianne Stallvik, Berit Nordstrand, Øistein Kristensen, Jørn Bathen, Eirik Skogvoll og Olav Spigset, som har kompetanse innenfor rusmedisin, klinisk farmakologi, kardiologi og statistikk. Studien ble finansiert med forskningsmidler fra Rusbehandling Midt-Norge, Sørlandet sykehus og St. Olavs hospital.

\section{Erlend Hem}

erlend.hem@medisin.uio.no

Tidsskriftet

\section{Litteratur}

1. Stallvik M, Nordstrand B, Kristensen $\emptyset$ et al. Corrected QT interval during treatment with methadone and buprenorphine - Relation to doses and serum concentrations. Drug Alcohol Depend 2012 e-publisert 16.10.2012

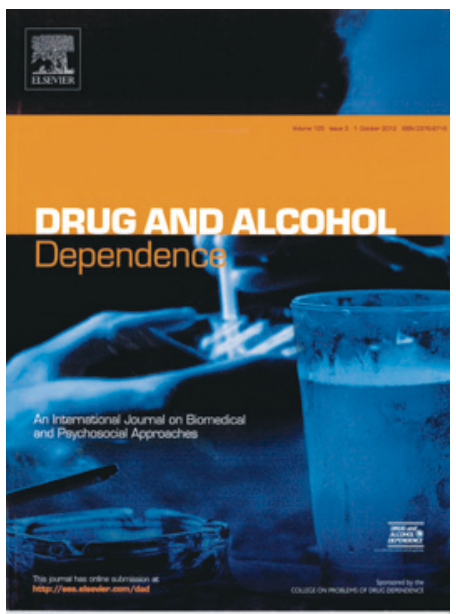

Artikkelen ble e-publisert 16.10. 2012 i det velrenommerte tidsskriftet Drug and Alcohol Dependence 